\title{
Protein degradation and amino acid metabolism by propionibacteria
}

\author{
T Langsrud, T Sørhaug, GE Vegarud
}

Department of Food Science, The Agricultural University of Norway, 1432 Aas, Norway

\begin{abstract}
Summary - This article reports the existing knowledge about the proteolytic system of Propionibacterium and its ability to degrade amino acids. Propionibacterium contains at least 2 weak proteinases, 1 cell wall-associated and 1 intracellular or membrane-bound. A wide variety of peptidases, such as amino peptidases, proline iminopeptidase, proline imidopeptidase, X-prolyl-dipeptidyl-aminopeptidase, endopeptidases and carboxypeptidase, has been described and characterized. A wide variety of amino acids, especially aspartic acid, alanine, serine and glycine, were easily degraded by Propionibacterium, but large strain and species variations were observed.
\end{abstract}

\section{Propionibacterium / proteinase / peptidase / amino acid}

Résumé - Dégradation protéique et métabolisme des acides aminés par les bactéries propioniques. Cet article fait l'état des connaissances actuelles sur le système protéolytique des bactéries propioniques, et sur sa capacité à dégrader des acides aminés. Propionibacterium contient au moins deux protéinases, l'une associée à la paroi cellulaire et l'autre cytoplasmique ou membranaire. Une vaste variété de peptidases ont été décrites et caractérisées, telles que aminopeptidases, proline iminopeptidase, proline imidopeptidase, X-prolyl-dipeptidyl-aminopeptidase, endopeptidases et carboxypeptidase. Une grande variété d'acides aminés, en particulier l'acide aspartique, l'alanine, la sérine et la glycine, pouvaient être facilement dégradés par Propionibacterium, mais de grandes variations dues à la souche et à l'espèce étudiée ont été observées.

\section{Propionibacterium / protéinase / peptidase / acide aminé}

\section{INTRODUCTION}

The dairy propionibacteria are essential for eye formation and the development of the characteristic sweet flavour in Emmenthaler and in Swiss-type cheeses (Sherman, 1921). Propionic and acetic acid and other volatile compounds have been implicated as providing part of the flavour complex in addition to amino acids, particularly proline and small peptides that are assumed to contribute to the sweet, nutty flavour (Langsrud and Reinbold, 1973; Biede and Hammond, 1979a, b). However, propionibacteria grow 
in synergism with thermophilic lactic starter bacteria in Emmenthaler cheese; thus, it is difficult to distinguish their individual contributions to proteolysis and the release of peptides and amino acids.

Very few reports on the proteolytic activity of propionibacteria appeared in the literature before the 1970s. Virtanen (1923) observed a slow growth and weak proteolysis by propionibacteria in milk at $37^{\circ} \mathrm{C}$ over a 2-month incubation period. However, the addition of peptone to milk increased the growth rate and the number of cells. Next, Berger et al (1938) found an intracellular tripeptidase in Propionibacterium pentosaceum. Klimovski et al (1965) concluded in their study on cheese ripening that dairy propionibacteria did not contribute significantly to proteolysis. However, Searles et al (1970) observed proteolytic activity of propionibacteria.

\section{PROTEIN DEGRADATION}

This was the background when we started work on protein degradation by propionibacteria in 1970. An important fact was that 1 amino acid, proline, was found in larger amounts in Swiss-type cheeses than in any other cheese, and that this amino acid could be important for the sweet, nutty flavour. Propionibacteria were shown to produce large amounts of proline from media containing casein hydrolysates, but there were large strain differences (Langsrud et al, 1977, 1978). Proline was mainly produced by peptidase action, and proline biosynthesis was of little significance. Although some proline was produced by proteolysis of casein, the rate was much slower than by peptidase action on casein hydrolysates. The release of proline from peptides coincided with autolysis of the propionibacteria (Østlie et al, 1995). A complex mixture of peptidase activities were observed using different assay substrates, and PAG elec- trophoresis of ultrasonic extracts from several Propionibacterium strains followed by zymogram detection showed 7 to 8 peptidase bands (Floberghagen et al, 1978; Østlie et al, 1995). The strains showed distinct differences in specificity, but all strains showed high activity towards substrates containing L-proline at the amino end. Proteinase activity of cell-free extracts was also detected by a zymogram technique with alpha-lactalbumin and cytochrome $\mathrm{c}$ as substrates (Ward, 1976), and 6 to 8 bands were observed.

The following discussion of recent results will first address the proteinase or caseinolytic activity of propionibacteria and then the peptidase activities.

\section{PROTEINASE ACTIVITY}

Caseinolytic activity of the cell-free extract from propionibacteria was shown by El Soda et al (1992). Preliminary purification studies of the caseinolytic activity of the cytoplasm from $P$ freudenreichii ATCC 9614 by ion exchange chromatography on Phast $Q$ Sepharose separated 3 caseinolytic fractions (Pripp et al, 1995). Caseinolytic activity was also observed in the postcultivation medium. Localization studies of different proteolytic activities of $P$ freudenreichii INF alpha and ATCC 9614 indicated caseinolytic activity with the cell wall and intracellularly (Sahiström et al, 1995b; Tobiassen et al, 1995b). Dupuis et al (1995) observed 2 types of proteolytic activities which could act on $\left[{ }^{14} \mathrm{C}\right] \beta$-casein or $\left[{ }^{14} \mathrm{C}\right] \alpha$-casein. The first enzyme activity was tightly bound to the cell wall and acted preferentially on $\beta$ casein. The second enzyme, the free proteinase activity, was released at the stationary phase probably by autolysis or by excretion. Indications are that this enzyme may be located in the cell membrane. The cell wall associated proteinases from 2 strains of $P$ freudenreichii were released 
from the cells by washing with a $\mathrm{Ca}^{2+-f r e e}$ buffer and assaying with tritiated casein as substrate (Sahlström et al, 1995b). The enzyme was purified and characterized. The proteinase(s) had a molecular mass of 41 $\mathrm{kDa}$, pl 4.0 , temperature optimum $51^{\circ} \mathrm{C}$ and $\mathrm{pH}$ optimum 7.0. The enzyme was inhibited by phenyl-methyl-sulfonylfluoride (PMSF), which shows that the enzyme is a serine proteinase. EDTA and o-phenanthroline had no inhibitory effect (not a regular metalloenzyme), but the enzyme was activated by reducing agents.

\section{PEPTIDASE ACTIVITY}

Peptidase localization studies by Sahlström et al (1989) with dipeptides and tripeptides as substrates in a zymogram technique showed 1 peptidase band associated with the cell wall, 2 to 3 peptidase bands associated with the membrane and 6 to 7 intracellular bands for the 2 strains tested. Peptidase studies of extracts from different species and strains of propionibacteria showed that they contain aminopeptidases, proline iminopeptidase and proline imidopeptidase (Perez Chaia et al, 1990; El-Soda et al, 1992; Østlie et al, 1995). In addition, greater activities of leucine aminopeptidase and proline iminopeptidase were observed in strains of $P$ freudenreichii (Perez Chaia et al, 1990). Studies by Tobiassen et al (1995b) indicated that propionibacteria in addition to the previously mentioned enzymes also contain an X-prolyl-dipeptidyl-aminopeptidase, mainly intracellular, an intracellular endopeptidase with CBZ-Gly-Gly-Leu-pNA as substrate and an endopeptidase with activity towards methionine enkephalin which was about $20 \%$ associated with the cell wall. This and later work indicate the possible presence of more than 1 endopeptidase (Pripp et al, 1995).

These reports show a great variety of proteolytic enzymes in propionibacteria capable of hydrolyzing many different pep- tides. This has been challenging for purification work to characterize individual enzymes and to clarify their role. The first publication was by Panon (1990), who isolated an intracellular proline iminopeptidase from $P$ freudenreichii 13673 by ionexchange chromatography on Fractogel TSK DEAE 650 and gel filtration on Sephacryl S-100 HR. The enzyme had a molecular mass of $61 \mathrm{kDa}$. Optimum activity was observed at $40^{\circ} \mathrm{C}$ and $\mathrm{pH} 8.0$. The proline iminopeptidase was a serine enzyme since it was inhibited by PMSF; divalent cations also inhibited this enzyme.

Sahlström et al (1989) reported the presence of a cell wall associated peptidase with an $\mathrm{Rf}$ value in PAGE of 57 and 0 , respectively, in $P$ freudenreichii ATCC 9614 and INF alpha. These 2 peptidases were purified by anion exchange chromatography on Q-Sepharose and gel filtration in Superose $6 \mathrm{~B}$. Both enzymes appeared to be metalloenzymes since they were inhibited by EDTA and o-phenanthroline. The enzyme with $\mathrm{Rf}$ value 57 had a molecular mass of $134 \mathrm{kDa}, \mathrm{pl} 4.2$, temperature optimum $42^{\circ} \mathrm{C}$ and $\mathrm{pH}$ optimum 8.6 , and was also inhibited by iodoacetic acid and $p$-mercuribenzoate, which indicates that sulfhydryl groups are important for the activity. The enzyme with $\mathrm{Rf}$ value 0 had a molecular mass of 86 $\mathrm{kDa}, \mathrm{pl}$ of 4.2 , temperature optimum $60^{\circ} \mathrm{C}$ and $\mathrm{pH}$ optimum 10, and was inhibited by iodoacetic acid, but not by $p$-mercuribenzoate. Both enzymes were active towards $\mathrm{N}$ benzoyl-Gly-Phe and N-benzoyl-Gly-Lys, indicating carboxypeptidase activity. Activity towards Leu-p-nitroanilide, Lys-p-NA and Ala-p-NA were absent or very low (Sahlström et al, 1995a).

An endopeptidase activity with bradykinin (Arg-Pro-Pro-Gly-Phe-Ser-Pro-Phe-Arg) as substrate was separated by Fast $Q$ Sepharose (Pripp et al, 1995) and further purified by hydroxyapatite, a second anion exchange chromatography on mono $Q$ followed by gel filtration on Superose 12 . The 
bradykinin-hydrolysing endopeptidase was a monomer of molecular mass $45 \mathrm{kDa}$, pl 5.2 , optimum $\mathrm{pH} 7-8$ and optimum temperature $50^{\circ} \mathrm{C}$. The purified enzyme also hydrolyzed CBZ-Phe-Arg-7-amido-4-methylcoumarin (PAM) and methionin enkephalin, but was free from aminopeptidase activity. The enzyme showed no activity towards $\alpha$ s1 casein (Tobiassen et al, 1995a).

Even with the present relatively limited work on the proteolytic enzymes of dairy propionibacteria, they appear to be equipped with many of the enzymes necessary to produce amino acids and small peptides from (milk) proteins. The caseinolytic activity is so low that detection is possible only with the most sensitive methods. Thus, propionibacteria grow very slowly in milk; however, the addition of peptides in protein hydrolysates (eg Tryptone) stimulates for faster growth. The situation in Swiss-type cheeses is somewhat comparable because lactic acid bacteria, particularly some lactobacilli, are clearly more proteolytic than propionibacteria and should therefore contribute to amino- $\mathrm{N}$ availability during the early stages of proteolysis. Because the cell wall associated proteinase action of propionibacteria is not sufficient for effective growth, it may be conjectured that the enzyme has some other function, for instance, as an activator of proautolysin (Ghuysen and Shockman, 1973). In comparing it with the lactococci, most of the same proteolytic activities are found in both. However, detailed studies of individual enzymes also reveal interesting differences. The main endopeptidase from $P$ freudenreichii ATCC 9614 was not inhibited by phosphoramidon and only slightly by $\beta$ casein $158-72$ in contrast to the endopeptidase from Lactococcus lactis subsp lactis M 1363 (Stepaniak et al, 1995), which was strongly inhibited by both compounds. Another difference is that propionibacteria show much higher proline iminopeptidase activity than lactococci (Tobiassen et al, 1995b).
The cell wall associated peptidases from $P$ freudenreichii ATCC 9614 and INF alpha both expressed carboxypeptidase activity (Sahlström et al, 1995a). Among the lactic acid bacteria, there is no report of carboxypeptidase activity in lactococci and only Lactobacillus casei has been shown to contain this activity (Pritchard and Coolbear, 1993).

Concerning the $\mathrm{CO}_{2}$ production in Swisstype cheeses, it exceeds the amount expected from lactate metabolism by propionibacteria. The difference may be explained by degradation of amino acids by propionibacteria or from growth of a secondary flora. Antila (1957) observed that many amino acids are catabolized by resting cells of propionibacteria. However, amino acid decarboxylase activity has not been reported for propionibacteria. Brendehaug and Langsrud (1985) studied the metabolism of amino acids in resting cell suspensions of $P$ freudenreichii strains under aerobic and anaerobic conditions and observed a rapid degradation of aspartic acid, serine, glycine and alanine and a slower degradation of some of the other amino acids, Other species of propionibacteria showed slower or no degradation at all. Parallel with the degradation, increases were observed for ammonia, propionic and acetic acid and in $\mathrm{CO}_{2}$. More detailed studies have been performed on the degradation of aspartic acid and alanine (Crow, 1986a, 1987; Rosner and Schink, 1990). The aspartase activity was already identified in propionibacteria by Virtanen and Tarnanen in 1932 , and the enzyme was later isolated and characterized (Ellfolk, 1953a, b). Observation showed that aspartic acid was the only amino acid that was metabolized during lactate fermentation in a complex medium (about $70 \%$ ). In a defined medium, more than $90 \%$ was metabolized after lactate exhaustion. Aspartate was only metabolized in the presence of propionate, and then according to the equation suggested by Crow (1986a): 
3 aspartate + propionate $\longrightarrow 3$ succinate + acetate $+\mathrm{CO}_{2}+\mathrm{NH}_{3}$

Alanine was only metabolized after exhaustion of lactate, which is also probably true for the other amino acids which are metabolized. Alanine dehydrogenase activity in propionibacteria was reported by Castberg and Morris (1978), and the enzyme was later studied by Crow (1987). Late degradation of alanine may be caused by the high content of pyruvate in propionibacteria from the lactate fermentation (Crow, 1986b) which inhibits the alanine dehydrogenase. After depletion of pyruvate, alanine was degraded according to the following equation:

3 alanine $\longrightarrow 2$ propionate + acetate $+\mathrm{CO}_{2}$ $+3 \mathrm{NH}_{3}$

To our present knowledge, dairy propionibacteria are endowed with proteolytic activities which apparently enable them to supply amino- $\mathrm{N}$ from proteins. Only a few of the enzymes have been purified and characterized, and the location of several enzymes needs to be determined. The properties of some of the enzymes differ from their counterparts in lactic acid bacteria.

The dairy propionibacteria are also capable of actively metabolizing some of the amino acids released. Details of these conversions should be the focus of future research. In order to better understand amino- $\mathrm{N}$ metabolism in propionibacteria, an important research area to investigate would be the transport system for amino acids and peptides. The protein/peptide hydrolysis and amino acid degradation provide amino acids (proline and other components) and $\mathrm{CO}_{2}$ which contribute to the flavour and eye formation in Swiss-type cheeses.

\section{REFERENCES}

Antila M (1957) Der Aminosảureabbau durch Propionsäurebakterien. Finn J Dairy Sci 18, 3-11
Berger J, Johnson MJ, Peterson WH (1938) The proteolytic enzymes of bacteria. II. The peptidases of some common bacteria. J Bacteriol 36, 521-543

Biede SL, Hammond EG (1979a) Swiss cheese flavor. I. Chemical analysis. J Dairy Sci 62, 227-237

Biede SL, Hammond EG (1979b) Swiss cheese flavor. II. Organoleptic analysis. J Dairy Sci 62, 238-248

Brendehaug J, Langsrud T (1985) Amino acid metabolism in propionibacteria: resting cells experiments with four strains. J Dairy Sci 68, 281-289

Castberg HB, Morris HA (1978) The pyruvate oxidizing system of Propionibacterium freudenreichii subsp shermanii. Milchwissenschaft $33,541-544$

Crow VL (1986a) Metabolism of aspartate by Propionibacterium freudenreichii subsp shermanii: effect on lactate fermentation. Appl Environ Microbiol 52, 359365

Crow VL (1986b) Utilization of lactate isomers by Propionibacterium freudenreichii subsp shermanii: regulatory role for intracellular pyruvate. Appl Environ Microbiol 52, 352-358

Crow VL (1987) Properties of alanine dehydrogenase and aspartase from Propionibacterium freudenreichii subsp shermanii. Appl Environ Microbiol 53, 1885-1892

Dupuis C, Corre C, Boyaval P (1995) Proteinase activity of dairy Propionibacterium. Appl Microbiol Biotechnol 42, 750-755

Ellfolk N (1953a) Studies on aspartase. I. Quantitative separation of aspartase from bacterial cells and its partial purification. Acta Chem Scand 7, 824-830

Ellfolk N (1953b) Studies on aspartase. II. On the chemical nature of aspartase. Acta Chem Scand 7, 11551163

El-Soda M, Ziada N, Ezzat N (1992) The intracellular peptide-hydrolase system of Propionibacterium. Microbios 72, 65-74

Floberghagen V, Sorhaug T, Langsrud T (1978) Peptide hydrolases in propionibacteria. Brief commun. In: 20 Int Dairy Congr, Paris, France

Ghuysen JM, Shockman GD (1973) Biosynthesis of peptidoglycan. In: Bacterial Membranes and Walls (L Leive, ed) Marcel Dekker, Inc, New York, NY, USA

Klimovskii I, Alekseeva K, Chekalova K (1965) Propionic acid bacteria and their effect on the biochernical processes and quality of Soviet cheese. Molochn Prom 26, 16-18 [Dairy Sci Abstr 27, 1821 (1965)]

Langsrud T, Reinbold GW (1973) Flavor development and microbiology of Swiss cheese a review. II. Starters, manufacturing processes and procedures. J Milk Food Technol 36, 531-542

Langsrud T, Reinbold GW, Hammond EG (1977) Proline production by Propionibacterium shermanii P59. J Dairy Sci 60, 16-23 
Langsrud T, Reinbold GW, Hammond EG (1978) Free proline production by strains of propionibacteria. J Dairy Sci 61, 303-308

Østlie H, Floberghagen V, Reinbold GW, Hammond EG, Vegarud G, Langsrud T (1995) Autolysis of dairy propionibacteria: growth studies, peptidase activities and proline production. J Dairy Sci 78, 1224-1237

Panon G (1990) Purification and characterization of a proline iminopeptidase from Propionibacterium shermanii 13673. Lait 70, 439-452

Perez Chaia A, Pesce de Ruiz Holgado A, Oliver G (1990) Peptide hydrolases of propionibacteria: effect of $\mathrm{pH}$ and temperature. J Food Prot 53, 237-240

Pripp AH, Tobiassen RO, Stepaniak L, Sorhaug T (1995) Endopeptidases and aminopeptidases from Propionibacterium freudenreichii 9614. Distribution and partial separation of intracellular fraction. In: Poster First Int Symp Dairy Propionibacteria, Rennes, France, 17-19 May

Pritchard GG, Coolbear T (1993) The physiology and biochemistry of the proteolytic system in lactic acid bacteria. FEMS Microbiol Rev 12, 179-206

Rosner B, Schink B (1990) Propionate acts as carboxylic group acceptor in aspartate fermentation by Propionibacterium freudenreichii. Arch Microbiol 155, 46-51

Sahlström S, Espinosa C, Langsrud T, Sorhaug T (1989) Cell wall, membrane, and intracellular peptidase activities of Propionibacterium shermanii. J Dairy Sci $72,342-350$

Sahlström S, Langsrud T, Sorhaug T (1995a) Characterization of peptidase activities associated with cell walls of Propionibacterium freudenreichii. In: Poster First Int Symp. Dairy Propionibacteria, Rennes, France, 17-19 May
Sahlström S, Vagias G, Langsrud T, Sorhaug T (1995b) Characterization of proteinase associated with the cell wall of Propionibacterium freudenreichii. In: Poster First Int Symp Dairy Propionibacteria, Rennes, France, 17-19 May

Searles MA, Argyle PJ, Chandan RC, Gordon JF (1970) Lipolytic and proteolytic activities of lactic cultures. In: 18 Int Dairy Congr, Sydney, Australia, 1E, 111

Sherman JM (1921) The cause of eyes and characteristic flavor in Emmental and Swiss cheese. J Bacteriol $6,379-392$

Stepaniak L, Fox PF, Sorhaug T, Grabska J (1995) Effect of peptides from the sequence 58-72 of beta-casein on the activity of endopeptidase, aminopeptidase, and X-prolyl-dipeptidyl aminopeptidase from Lactococcus lactis ssp lactis MG 1363. J Agric Food Chem $43,849-853$

Tobiassen RO, Pripp AH, Stepaniak L, Sletten K, Sorhaug T (1995a) Purification and characterization of an endopeptidase from Propionibacterium freudenreichii ATCC 9614. In: Poster First Int Symp Dairy Propionibacteria, Rennes, France 17-19 May

Tobiassen RO, Stepaniak L, Sorhaug T (1995b) Screening of the proteolytic system of different starter organisms. In: Poster First Int Symp Dairy Propionibacteria, Rennes, France, 17-19 May

Virtanen Al (1923) Über die Propionsäuregärung. Soc Sci Fennica Comment Physic-Math 1(36), 23

Virtanen Al, Tarnanen J (1932) Die enzymatische Spaltung und Synthese der Asparaginsäure. Biochem Z 250, 193-211

Ward WC (1976) Detection of proteolytic enzymes in polyacrylamide gels. Anal Biochem 74, 242-245 